\title{
Cardiac biomarkers in chronic kidney disease are independently associated with myocardial edema and diffuse fibrosis by cardiovascular magnetic resonance
}

Luca Arcari ${ }^{1,2}$, Juergen Engel ${ }^{3}$, Tilo Freiwald ${ }^{3}$, Hui Zhou ${ }^{1,4}$, Hafisyatul Zainal ${ }^{1,5}$, Monika Gawor ${ }^{6}$, Stefan Buettner ${ }^{3}$, Helmut Geiger ${ }^{3}$, Ingeborg Hauser ${ }^{3}$, Eike Nagel ${ }^{1}$ and Valentina O. Puntmann ${ }^{1 *}$ (D)

\begin{abstract}
Background: High sensitivity cardiac troponin T (hs-cTnT) and NT-pro-brain natriuretic peptide (NT-pro BNP) are often elevated in chronic kidney disease (CKD) and associated with both cardiovascular remodeling and outcome. Relationship between these biomarkers and quantitative imaging measures of myocardial fibrosis and edema by 11 and T2 mapping remains unknown.

Methods: Consecutive patients with established CKD and estimated glomerular filtration rate $(e G F R)<59 \mathrm{ml} /$ $\mathrm{min} / 1.73 \mathrm{~m}^{2}(\mathrm{n}=276)$ were compared to age/sex matched patients with eGFR $\geq 60 \mathrm{ml} / \mathrm{min} / 1.73 \mathrm{~m}^{2}(\mathrm{n}=242)$ and healthy controls $(n=38)$. Comprehensive cardiovascular magnetic resonance $(C M R)$ with native T1 and T2 mapping, myocardial ischemia and scar imaging was performed with venous sampling immediately prior to CMR.

Results: Patients with CKD showed significant cardiac remodeling in comparison with both healthy individuals and non-CKD patients, including a stepwise increase of native T1 and T2 ( $p<0.001$ between all CKD stages). Native T1 and $T 2$ were the sole imaging markers independently associated with worsening CKD in patients $[B=0.125(95 \% \mathrm{Cl}$ $0.022-0.235)$ and $\mathrm{B}=0.272$ (95\% Cl 0.164-0.374) with $\mathrm{p}=0.019$ and $<0.001$ respectively]. At univariable analysis, both hs-CTnT and NT-pro BNP significantly correlated with native T1 and T2 in groups with eGFR 30-59 ml/min/1.73 $\mathrm{m}^{2}$ and eGFR $<29 \mathrm{ml} / \mathrm{min} / 1.73 \mathrm{~m}^{2}$ groups, with associations being stronger at lower eGFR (NT-pro BNP (log transformed, lg10): native $T 1 r=0.43$ and $r=0.57$, native $T 2 r=0.39$ and $r=0.48$ respectively; log-transformed hs-cTnT(Ig10): native $\mathrm{T} 1 \mathrm{r}=0.23$ and $r=0.43$, native $\mathrm{T} 2 \mathrm{r}=0.38$ and $r=0.58$ respectively, $p<0.001$ for all, $p<0.05$ for interaction). On multivariable analyses, we found independent associations of native T1 with NT-pro BNP $[(B=0.308(95 \% \mathrm{Cl}$ $0.129-0.407), p<0.001$ and $B=0.334$ (95\% Cl 0.154-0.660), $p=0.002$ for eGFR 30-59 ml $/ \mathrm{min} / 1.73 \mathrm{~m}^{2}$ and eGFR $<29 \mathrm{ml} / \mathrm{min} / 1.73 \mathrm{~m}^{2}$, respectively] and of 2 with hs-cTnT $[B=0.417$ (95\% Cl 0.219-0.650), $\mathrm{p}<0.001$ for eGFR $<29 \mathrm{ml} /$ $\left.\mathrm{min} / 1.73 \mathrm{~m}^{2}\right]$.
\end{abstract}

\footnotetext{
*Correspondence: valentina.puntmann@icloud.com

${ }^{1}$ Institute of Experimental and Translational Cardiovascular Imaging,

DZHK Centre for Cardiovascular Imaging, Goethe University Hospital

Frankfurt, Frankfurt am Main, Germany

Full list of author information is available at the end of the article
}

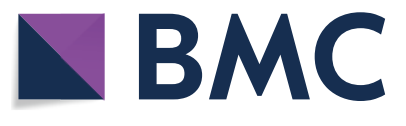

(c) The Author(s) 2021. Open Access This article is licensed under a Creative Commons Attribution 4.0 International License, which permits use, sharing, adaptation, distribution and reproduction in any medium or format, as long as you give appropriate credit to the original author(s) and the source, provide a link to the Creative Commons licence, and indicate if changes were made. The images or other third party material in this article are included in the article's Creative Commons licence, unless indicated otherwise in a credit line to the material. If material is not included in the article's Creative Commons licence and your intended use is not permitted by statutory regulation or exceeds the permitted use, you will need to obtain permission directly from the copyright holder. To view a copy of this licence, visit http://creativecommons.org/licenses/by/4.0/. The Creative Commons Public Domain Dedication waiver (http://creativeco mmons.org/publicdomain/zero/1.0/) applies to the data made available in this article, unless otherwise stated in a credit line to the data. 
Conclusions: We demonstrate independent associations between cardiac biomarkers with imaging markers of interstitial expansion, which are CKD-group specific. Our findings indicate the role of diffuse non-ischemic tissue processes, including excess of myocardial fluid in addition to diffuse fibrosis in CKD-related adverse remodeling.

Keywords: Chronic kidney disease, Heart failure, Myocardial remodeling, Troponin, Edema, Cardiovascular magnetic resonance

\section{Background}

Chronic kidney disease (CKD) and heart failure (HF) often coexist and worsening renal function is a strong predictor of poor cardiovascular outcome [1]. Patients with CKD have very high risk of cardiovascular disease (CVD), yet high CVD morbidity and mortality is only partially explained by the complications from atherosclerotic coronary artery disease (CAD). Phenotypically, HF in CKD is characterized by preserved left ventricular (LV) systolic function, eccentric remodeling and increased diastolic stiffness [2-4]. Markedly raised troponin and $\mathrm{N}$-terminal pro-brain natriuretic peptide (NT-pro BNP), the markers of myocardial injury and increased wall-stress, respectively, are also frequently found in CKD. Both markers are associated with poor prognosis in CKD, and especially with the HF-associated outcomes [5-8]. Although their significance remains controversially discussed and had been related to impaired renal elimination, recent reports imply that a sustained, subclinical, non-ischemic myocardial injury is more likely to explain the raised levels of these markers in CKD [9].

Myocardial T1 and T2 mapping with cardiovascular magnetic resonance (CMR) allows quantifiable tissue characterization and provide direct measures of the pathological myocardial processes non-invasively [10]. Native T1 is a non-specific measure of abnormal myocardium; it can relate to myocardial fibrosis, edema or infiltration [10]. Native T2 is water-specific, indicating excess myocardial fluid, which co-localizes with myocardial processes, such as edema, injury and/or inflammation [10]. Several studies revealed higher native T1 values in CKD patients [11], whereas more recently, a correlation of native $\mathrm{T} 1$ and troponin has also been shown [12]. A single previous study revealed raised $\mathrm{T} 1$ and T2 markers in participants with severe CKD on hemodialysis [13]. Native T1 of non-scarred myocardium is a strong predictor of survival, CVD mortality and incidence of HF in ischemic and non-ischemic cardiac conditions $[14,15]$. No study to date comprehensively examined the relationship between these imaging measures and myocardial changes in CKD, nor related these to the serological markers of myocardial injury and increased wall stress, high-sensitive cardiac troponin $\mathrm{T}$ (hs-cTnT) and NT-pro BNP.

\section{Methods}

This is a prospective longitudinal observational investigator-led study of $\mathrm{T} 1$ in adult patients undergoing a clinically indicated CMR examination, in line with cardiological practice guidelines (Consort diagram, Fig. 1). Consecutive patients with established diagnosis of CKD $[16,17]$ and reduced estimated glomerular filtration rate (eGFR) $<59 \mathrm{ml} / \mathrm{min} / 1.73 \mathrm{~m}^{2}$ using the Modification of Diet in Renal Disease (MDRD) formula (the CKD stages 3-5; TRUE-TypeCKD Study NCT03749551) ongoing recruitment since March 2018) were enrolled. The CKD diagnosis was established independently by nephrologists and defined as abnormalities of kidney function or structure present for more than 3 months and eGFR $<59 \mathrm{ml} /$ $\min / 1.73 \mathrm{~m}^{2}$ on at least two occasions separated by a period of at least 90 days (with or without markers of kidney damage) $[16,17]$. An independent cohort of controls with eGFR $\geq 60 \mathrm{ml} / \mathrm{min} / 1.73 \mathrm{~m}^{2}$ (including CKD stages 1 and $2[16,17])$, matched for age, gender and traditional CVD risk factor profile, was sourced from the ongoing International T1 Outcome Study using propensity score matching (PSM, $\mathrm{n}=242$, recruited between 03/16 to 03/19 (NCT03749343), ongoing recruitment since March 2016). The details of both registries, inclusion/exclusion criteria, imaging protocols and sequence parameters were reported previously $[14,15,18]$, and are included in Additional file 3. A further group of healthy controls $(n=38)$ with similar age and sex distribution was gathered from an ongoing multicenter study including healthy individuals without CVD risk factors or any regular medication (NCT04444128). Exclusion criteria were known specific cardiomyopathies, valvular heart disease or myocarditis, known allergy to gadolinium-based contrast agents (GBCA), and CMR unsafe implants or devices. All procedures were carried out in accordance with the Declaration of Helsinki (2013). All participants were informed about the possible risks of nephrogenic systemic fibrosis (NSF), as per regulatory guidelines (Food and Drug Administration, European Medicine Agency, American College of Radiology [19]). Administration of GBCA to the CKD patients was in any case strictly performed following guidelines indication [20]. Patients on hemodialysis were scheduled to receive this within $24 \mathrm{~h}$ from the administration of the GBCA. All participants with significant CKD were screened for 


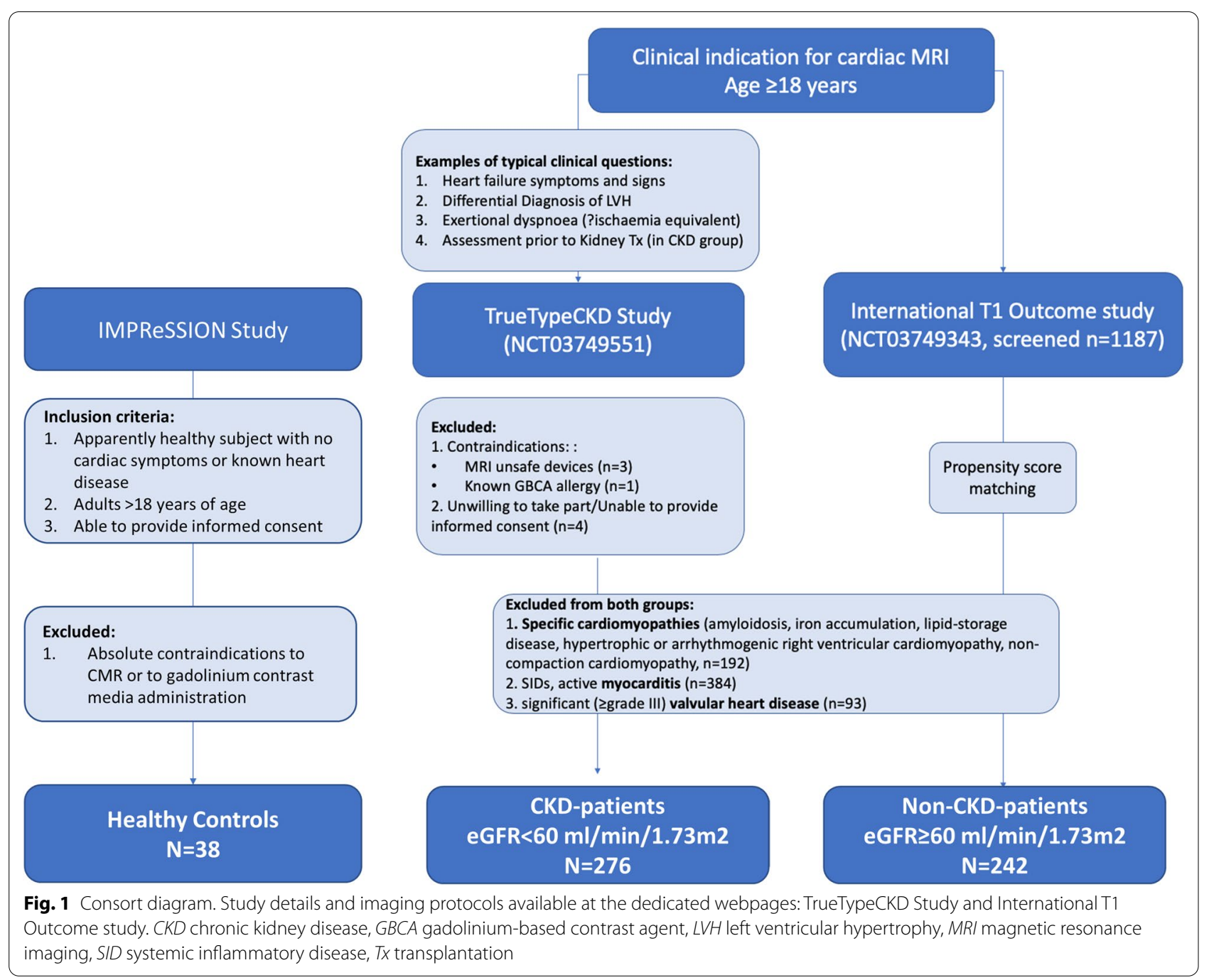

symptoms of NSF at regular 6-monthly intervals. The study protocols were reviewed and approved by institutional ethics committee. Written informed consent was obtained from all participants.

Clinical meta-data, including systolic/diastolic blood pressure (BP), body mass index (BMI), presence of traditional CVD risk factors, symptoms, medication were collected for all participants. Respiratory variation of inferior vena cava (IVC) from transthoracic echocardiography performed within $30 \mathrm{~min}$ from the index CMR was used as an index of fluid status, obtainable in all subjects. Loop diuretics use was not considered a reliable marker of volume status in CKD patients, since hemodialysis patients with no urine production would likely have volume overload and no diuretics intake. All participants underwent a standardized CMR using a 3T clinical CMR scanner (Skyra, software version VE11, Siemens Healthineers, Erlangen, Germany) for acquisition of cardiac function, volumes, mass, myocardial T1 and T2 mapping (Fig. 2), myocardial perfusion and scar imaging. T1 mapping was performed using an in-house developed variant of the modified Look-Locker Imaging sequence (Frankfurt Main, FFM-MOLLI) [10]. For T2 mapping, a T2-FLASH sequence was employed [21]. All T1 and T2 mapping values were determined by these same sequences, where both have established normal ranges, which were previously published using identical sequence parameters [22, 23]. Myocardial perfusion imaging was performed using vasodilation (regadenoson, $400 \mathrm{mcg} / 5 \mathrm{ml}$ ) and administration of $0.1 \mathrm{mmol} / \mathrm{kg}$ body weight gadobutrol $\left(\right.$ Gadovist $^{\circledR}$, Bayer Healthcare, Berlin, Germany) [24]. The presence of myocardial scar was visualized by late gadolinium enhancement (LGE) $15 \mathrm{~min}$ after GBCA administration.

Transthoracic echocardiography was performed by board-certified cardiologists within 30 min of completion of CMR examination with participants lying supine in left lateral position (Vivid E95, General Electric Healthcare, 
Chicago, Illinois, USA) for respiratory variation of IVC, as a measure of volume status, using postprocessing recommendation [25].

Analysis of cardiac volumes, function and mass was performed using semiautomated contour detection (SuiteHeart $^{\circledR}$, Neosoft, Pewaukee, Wisconsin, USA). Interpretation of myocardial perfusion and LGE images was performed following standardized postprocessing recommendations. Myocardial LGE was visually defined by a minimum of two observers based on the presence and predominant pattern as ischemic or non-ischemic [26]. All observers were board-certified cardiologists holding established accreditations of CMR competencies. Quantitative tissue characterization and myocardial deformation analysis were performed by the core-lab staff (Goethe CVI, Frankfurt/Main, Germany), blind to the underlying participant group allocation. Myocardial $\mathrm{T} 1$ and $\mathrm{T} 2$ were measured conservatively within septal myocardium of midventricular short axis slice, using motion-corrected scanner-derived images, as per internal standardized operating procedures [10, 27]. Areas of LGE were excluded from region of interest to avoid inclusion of areas with replacement scar. Global longitudinal (GLS) and circumferential strain (GCS) were measured using CMR feature tracking $\left(\right.$ MEDIS ${ }^{\circledR}$, Leiden, The Netherlands) [28].

All participants underwent venous blood sampling immediately prior to CMR study. Bloods samples were spun and frozen at $-80{ }^{\circ} \mathrm{C}$ and analyzed subsequently using standardized commercially available test kits Analysis hs-cTnT and NT-pro BNP (Elecsys 2010 ${ }^{\circledR}$, Roche, Basel, Switzerland). The cut-offs for hs-cTnT and NT-pro BNP were used to define normal/abnormal in all subjects (using a cut of value of 99 percentile of $13.9 \mathrm{ng} / \mathrm{l}$ [8] and $>300 \mathrm{pg} / \mathrm{l}$ [3], respectively).

\section{Statistical analysis}

Staistical analysis was performed using SPSS (version 25.0, Statistical Package for the Social Sciences, International Business Machines, Inc., Armonk, New York, USA and R Plug-in for PSM). Data are presented in counts (percentages), mean \pm standard deviation (SD) or median (interquartile range, IQR), as appropriate. Group comparisons were performed using paired and independent t-test or one-way ANOVA, $\mathrm{Chi}^{2}$, MannWhitney test, and Fischer's exact tests as appropriate. Correlation analysis was performed (graphically reported) to assess relationships between serological and imaging markers at various degrees of renal function. The interaction of imaging markers with status of CKD in patients (eGFR $\geq 90 \mathrm{ml} / \mathrm{min} / 1.73 \mathrm{~m}^{2}$, eGFR 60-89 $\mathrm{ml} / \mathrm{min} / 1.73 \mathrm{~m}^{2}$, eGFR $30-59 \mathrm{ml} / \mathrm{min} / 1.73 \mathrm{~m}^{2}$, eGFR $<29 \mathrm{ml} / \mathrm{min} / 1.73 \mathrm{~m}^{2}$ ) was examined using univariable and multivariable linear regression. Relationships within the CKD strata were tested for interaction. The associations between serological and imaging measures were explored using by univarible and multivariable linear regressions. Since serum biomarkers displayed a highly skewed distribution, log-transformed values were used to achieve approximate normal distribution when performing regression analysis. Analysis of collinearity was performed by correlation matrix, where a correlation of \pm 0.7 or weaker was used as cut-off for inclusion of variables within the same multivariable model. This criterion was not satisfied by LV end-diastolic volume (LVEDV) and LV end-systolic volume (LVESV) that showed closer correlation; hence, LVEDV only was included in the multivariable models. We included in the multivariable models those variables that had $\mathrm{p}<0.05$ at univariable analysis, plus all those having biological plausibility. Multivariable analysis was performed by stepwise regression. We estimated that a sample size of 37 per group was needed to achieve $80 \%$ power to detect continuous associations with a coefficient of determination $r^{2}=0.20$, using a 2 -sided hypothesis test with a significance level of 0.05 . PSM was performed using 1:k optimal matching algorithm based on the following variables: traditional CVD risk factors (age, sex, presence of hypertension, diabetes, smoking, hyperlipidemia). Reproducibility of CMR measurements were assessed using Bland-Altman analyses. All tests were two-tailed and p-value of $<0.05$ was considered statistically significant.

\section{Results}

Baseline population characteristics for groups of patients and healthy controls are summarized in Table 1. Significant differences were observed between healthy controls and both non-CKD (eGFR $\left.\geq 60 \mathrm{ml} / \mathrm{min} / 1.73 \mathrm{~m}^{2}\right)$ and CKD $\left(e G F R<59 \mathrm{ml} / \mathrm{min} / 1.73 \mathrm{~m}^{2}\right)$ patients' groups regarding native $\mathrm{T} 1$ and $\mathrm{T} 2$ which were lower in controls (Table 2, Fig. 3 p $<0.001$ for all comparisons). Compared to patients with eGFR $\geq 60 \mathrm{ml} / \mathrm{min} / 1.73 \mathrm{~m}^{2}$, patients with eGFR $<59 \mathrm{ml} / \mathrm{min} / 1.73 \mathrm{~m}^{2}$ had higher hs-cTnT, NT-pro BNP and lower hematocrit $(\mathrm{p}<0.05)$. The two groups were similar for New York Heart Association class, and most cardiac medications, apart from the higher rate of aldosterone and neprilysin inhibitors in controls, and loop diuretics in the eGFR $<59 \mathrm{ml} / \mathrm{min} / 1.73 \mathrm{~m}^{2}$ group ( $\mathrm{p}<0.05$ for all). The eGFR $<59 \mathrm{ml} / \mathrm{min} / 1.73 \mathrm{~m}^{2}$ group also had higher LV volumes and mass, myocardial native T1 and T2 (Fig. 3), and lower LV ejection fraction (LVEF), GCS and IVC respiratory variation (Table 2, $\mathrm{p}<0.01$ for all). A third of all patients had myocardial scar by LGE with no overall difference in proportions between the patients' groups for the presence $(\mathrm{p}=0.15)$ or patterns (ischemic vs. non-ischemic, $\mathrm{p}=0.63$ vs. 0.37 , 

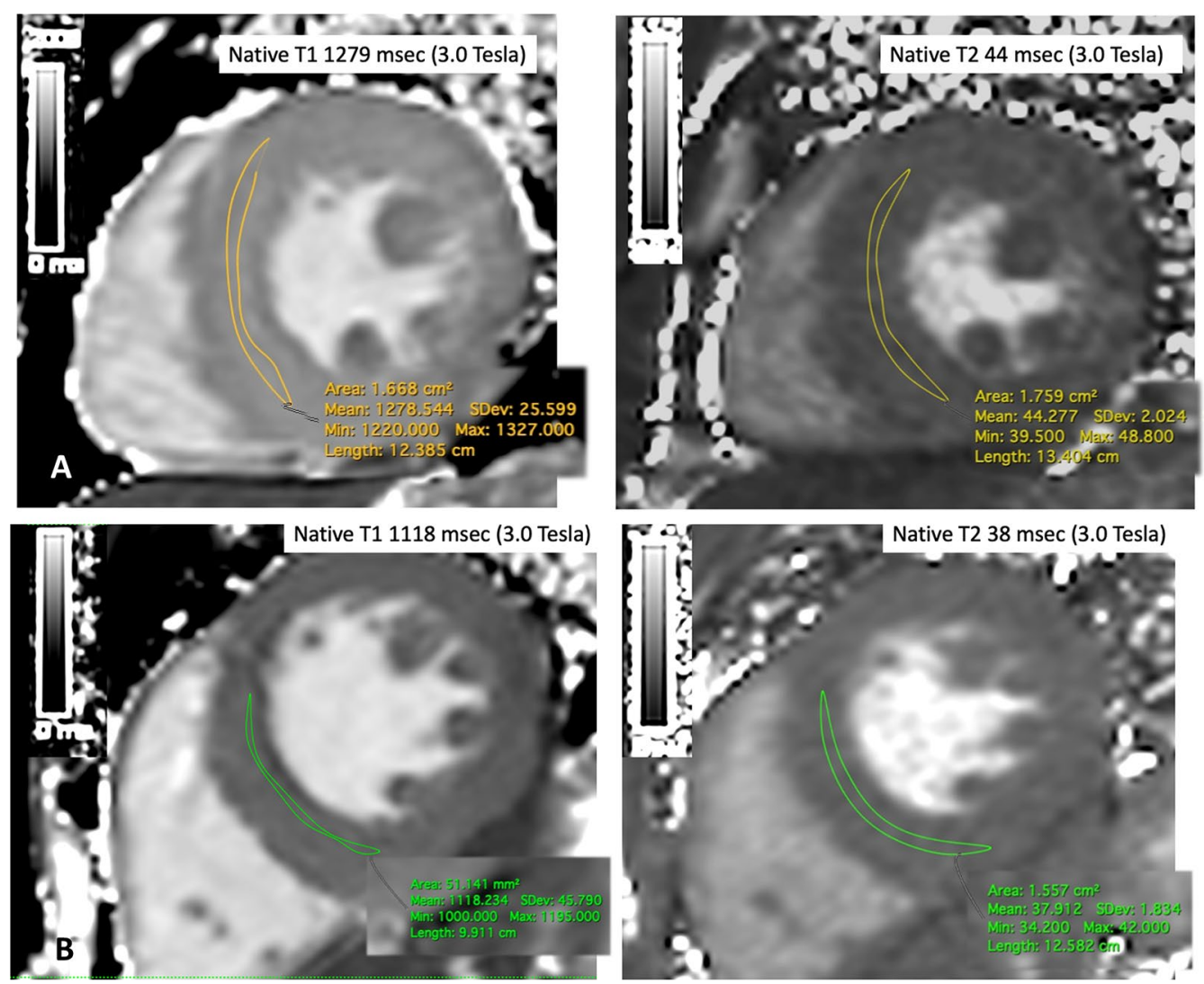

Fig. 2 Representative measurement of native T1 and T2 in a CKD patient (a) and a control (b) Native T1 and T2 measurements (mean midventricular septal ROI measurement, normal values for native T1 using FFM-MOLLI: 3.0-T: mean of the normal range $1052 \pm 23$ ms; i.e. upper limit of normal range: $1098 \mathrm{~ms}$ at $3 \mathrm{~T})$, native T2: T2-FLASH sequence $35 \pm 2 \mathrm{~ms}$ )

respectively). Patient groups were also similar for the presence of relevant myocardial ischemia $(\mathrm{p}=0.10)$; this was treated with revascularization, if amenable target vessel was identified.

\section{Pre and post-hemodialysis comparisons}

A total of 10 participants with severe CKD on HD underwent a repeat native CMR (Fig. 4) immediately after completed HD. There was a reduction of native T2 (mean difference \pm standard deviation $=2.40 \pm 1.53 \mathrm{~ms}$, $\mathrm{p}<0.001)$, LVEDV $(4.0 \pm 1.4 \mathrm{ml}, \mathrm{p}<0.001)$, and smaller IVC diameter $(3.1 \pm 2.4 \mathrm{~mm}, \mathrm{p}<0.001)$, but no significant change in LV mass $(1.9 \pm 1.2 \mathrm{~g}, \mathrm{p}=0.09)$. The mean difference in myocardial T2, LVEDV and LV mass were all proportional to the amount of removed ultrafiltration volume $(r=0.72, r=0.65$ and $r=0.41$ respectively, $\mathrm{p}<0.001$ for all).

\section{Analysis of relationships}

Subgroups stratified by eGFR showed differentially significant associations between hs-cTnT and native $\mathrm{T} 1$ and T2 (Fig. 5, Additional file 1: Figure S1 and Additional file 2: Figure S2). Overall, the relationships between the two tissue imaging markers, serological biomarkers and measures of structural remodeling were stronger in the eGFR $<59 \mathrm{ml} / \mathrm{min} / 1.73 \mathrm{~m}^{2}$ group. Also, there was a stronger inter-relationship between native $\mathrm{T} 1$ and $\mathrm{T} 2$ as eGFR declined (eGFR $\geq 60 \mathrm{ml} / \mathrm{min} / 1.73 \mathrm{~m}^{2}$ vs. eGFR $30-59 \mathrm{ml} / \mathrm{min} / 1.73 \mathrm{~m}^{2}$ vs. eGFR $<29 \mathrm{ml} / \mathrm{min} / 1.73 \mathrm{~m}^{2}$, $\mathrm{r}=0.295$. vs $\mathrm{r}=0.607$ vs $\mathrm{r}=0.560, \mathrm{p}<0.001$ for all, $\mathrm{p}<0.05$ for interaction). Both hs-cTnT and NT-pro BNP were significantly associated with native $\mathrm{T} 1$ and $\mathrm{T} 2$ in groups with eGFR $30-59 \mathrm{ml} / \mathrm{min} / 1.73 \mathrm{~m}^{2}$ and eGFR $<29 \mathrm{ml} /$ $\min / 1.73 \mathrm{~m}^{2}$ groups, with the association being stronger at the lower eGFR (log-transformed NT-pro BNP: native $\mathrm{T} 1 \mathrm{r}=0.43$ and $\mathrm{r}=0.57$, native $\mathrm{T} 2 \mathrm{r}=0.39$ and $\mathrm{r}=0.48$ respectively; log-transformed hs-cTnT: native T1 $\mathrm{r}=0.23$ and $\mathrm{r}=0.43$, native $\mathrm{T} 2 \mathrm{r}=0.38$ and $\mathrm{r}=0.58$ respectively, $\mathrm{p}<0.001$ for all, $\mathrm{p}<0.05$ for interaction); a weaker relationship was observed between hs-cTnT and native $\mathrm{T} 1$ and T2 in patients with eGFR $60-89 \mathrm{ml} / \mathrm{min} / 1.73 \mathrm{~m}^{2}$ $(\mathrm{r}=0.18$ and $\mathrm{r}=0.19$ with $\mathrm{p}=0.004$ and $\mathrm{p}=0.003$ respectively). IVC change during inspiration showed a negative correlation with both native $\mathrm{T} 1$ and $\mathrm{T} 2$, albeit only in 
Table 1 Participant characteristics

\begin{tabular}{|c|c|c|c|c|}
\hline Variable & $\begin{array}{l}\text { Healthy controls } \\
(n=38)\end{array}$ & $\begin{array}{l}\text { Patients }(e G F R \geq 60) \\
(n=242)\end{array}$ & $\begin{array}{l}\text { Patients }(e G F R<59) \\
(n=276)\end{array}$ & Sig (p-value)* \\
\hline Age (years) & $57 \pm 11$ & $56 \pm 19$ & $58 \pm 21$ & 0.13 \\
\hline Male (n, \%) & $24(63)$ & $145(60)$ & $189(65)$ & 0.24 \\
\hline Systolic BP (mmHg) & $121 \pm 11^{\circ}$ & $134 \pm 17$ & $137 \pm 21$ & 0.38 \\
\hline Diastolic BP (mmHg) & $75 \pm 6^{\circ}$ & $79 \pm 10$ & $78 \pm 12$ & 0.31 \\
\hline Heart rate (bpm) & $64 \pm 10$ & $73 \pm 13$ & $75 \pm 14$ & 0.29 \\
\hline Blood hematocrit (\%) & $42 \pm 4 \S$ & $41.3 \pm 5.2$ & $39.8 \pm 6.4$ & 0.004 \\
\hline $\operatorname{eGFR}\left(\mathrm{ml} / \mathrm{min} / 1.73 \mathrm{~m}^{2}\right)$ & $87(83-94)^{\circ}$ & $84(61-112)$ & $29(6-57)$ & $<0.001$ \\
\hline hs-CRP, mg/l & $0.2(0.1-0.3)^{\circ}$ & $3.9 \pm 0.9$ & $6.3 \pm 1.8$ & $<0.001$ \\
\hline hs-cTnT (ng/l) & $1(0-2)^{\circ}$ & $6(4-10)$ & $14(6-30)$ & 0.01 \\
\hline NT-pro BNP (pg/l) & $48(38-72)^{\circ}$ & $78(38-207)$ & $582(187-2192)$ & $<0.001$ \\
\hline$>300, n(\%)$ & / & $46(24)$ & $69(62)$ & $<0.001$ \\
\hline $\mathrm{NYHA} \geq \mathrm{III}(\mathrm{n}, \%)$ & / & $68(28)$ & $88(32)$ & 0.32 \\
\hline $\mathrm{BMI}\left(\mathrm{kg} / \mathrm{m}^{2}\right)$ & $23 \pm 2$ & $27 \pm 8$ & $26 \pm 9$ & 0.185 \\
\hline Blood hemoglobin (g/dl) & $14 \pm 1 \S$ & $14.2 \pm 1$ & $12.6 \pm 1$ & $<0.001$ \\
\hline Smoking (n, \%) & / & $48(20)$ & $66(24)$ & 0.274 \\
\hline Hypertension (n, \%) & / & $192(91)$ & $262(95)$ & 0.073 \\
\hline Diabetes (n, \%) & / & $116(48)$ & $143(52)$ & 0.364 \\
\hline Type II $(n, \%)$ & / & $87(36)$ & $112(41)$ & 0.244 \\
\hline Vasculitis (n, \%) & / & $39(16)$ & $52(19)$ & 0.546 \\
\hline Polycystic syndrome (n, \%) & / & $7(2)$ & $12(4)$ & 0.188 \\
\hline Hyperlipidemia (n, \%) & / & $150(62)$ & $188(68)$ & 0.153 \\
\hline Known CAD (n, \%) & / & $68(28)$ & $88(32)$ & 0.322 \\
\hline 3-vessel CAD or equivalent $(n, \%)$ & / & $32(13)$ & $48(17)$ & 0.205 \\
\hline Previous revascularization (n, \%) & / & $53(22)$ & $77(28)$ & 0.117 \\
\hline Previous diagnosis of HF $(n, \%)$ & / & $77(32)$ & $108(39)$ & 0.097 \\
\hline \multicolumn{5}{|l|}{ Cardiac medication } \\
\hline Beta blockers, n (\%) & / & $138(57)$ & $174(63)$ & 0.299 \\
\hline RAS inhibitors, n (\%) & / & 198(82) & $234(85)$ & 0.358 \\
\hline Aldosterone inhibitors (n, \%) & / & $68(28)$ & $33(12)$ & $<0.001$ \\
\hline Neprilysin inhibitors $(\mathrm{n}, \%)$ & / & $27(11)$ & $2(5)$ & 0.011 \\
\hline Calcium antagonists $(\mathrm{n}, \%)$ & / & $184(76)$ & $224(81)$ & 0.166 \\
\hline Loop diuretics (n, \%) & / & $68(28)$ & 199(72) & $<0.001$ \\
\hline Platelet inhibition (n, \%) & / & $138(57)$ & $136(51)$ & 0.172 \\
\hline Statins (n, \%) & / & $155(64)$ & 196(71) & 0.089 \\
\hline
\end{tabular}

Bold indicated $p$-value $<0.05$

Mean $\pm S D$, or median (IQR), $\mathrm{p}$-value $<0.05$ was considered significant

$B P$ blood pressure, eGFR estimated glomerular filtration rate $\left(\mathrm{ml} / \mathrm{min} / 1.73 \mathrm{~m}^{2}\right)$, $h s-C T n T$ high-sensitive troponin $\mathrm{T}, C A D$ coronary artery disease, $C R P C$-reactive protein, $H F$ heart failure, NT-proBNP N-terminal pro brain natriuretic peptide, NYHA New York Heart Association, RAS renin-angiotensin system

${ }^{*} \mathrm{p}$-value for differences between patients' groups (eGFR $\geq 60$ vs eGFR $<59$ )

${ }^{\circ} \mathrm{p}<0.05$ vs non-CKD and CKD patients' groups

${ }^{\S} \mathrm{p}<0.05$ vs CKD patients' group

patients with eGFR $<29 \mathrm{ml} / \mathrm{min} / 1.73 \mathrm{~m}^{2}(\mathrm{r}=-0.33$ and $\mathrm{r}=-0.36$, with $\mathrm{p}=0.003$ and $\mathrm{p}=0.001$ respectively).

In adjusted linear regression analyses, native $\mathrm{T} 1$ and T2 were independently associated with the status of worsening $C K D[B=0.125$ (95\% CI $0.022-0.235)$ and $\mathrm{B}=0.272$ (95\% CI 0.164-0.374), respectively] (Table 3).
Multivariable linear analyses (stepwise, forward, likelihood-ratio, including as independent variables also CMR measures of LV function, mass and scar as well as IVC respiratory variation as a measure of volume status, hematocrit and C-reactive protein concentration) revealed independent associations of NT-pro BNP with native T1 
Table 2 Cardiovascular magnetic resonance (CMR) and echocardiographic measurements of function, structure and tissue characterization

\begin{tabular}{|c|c|c|c|c|}
\hline Variable & $\begin{array}{l}\text { Healthy controls } \\
(n=38)\end{array}$ & $\begin{array}{l}\text { Patients }(\mathrm{eGFR} \geq 60 \mathrm{ml} / \\
\left.\mathrm{min} / 1.73 \mathrm{~m}^{2}\right) \\
(\mathrm{n}=242)\end{array}$ & $\begin{array}{l}\text { Patients }(\mathrm{eGFR}<59 \mathrm{ml} / \\
\left.\min / 1.73 \mathrm{~m}^{2}\right) \\
(\mathrm{n}=276)\end{array}$ & Sig (p-value)* \\
\hline LVEDV index, $\mathrm{ml} / \mathrm{m}^{2}$ & $80 \pm 11^{\circ}$ & $84 \pm 20$ & $93 \pm 30$ & $<0.001$ \\
\hline LVESV index, $\mathrm{ml} / \mathrm{m}^{2}$ & $31 \pm 5^{\circ}$ & $38 \pm 19$ & $46 \pm 31$ & $<0.001$ \\
\hline LVEF, \% & $61 \pm 5^{\circ}$ & $57 \pm 11$ & $53 \pm 17$ & $<0.001$ \\
\hline LV mass index, $\mathrm{g} / \mathrm{m}^{2}$ & $65 \pm 15 \S$ & $63 \pm 16$ & $70 \pm 21$ & $<0.001$ \\
\hline RVEF, \% & $62 \pm 8^{\circ}$ & $57 \pm 9$ & $56 \pm 13$ & 0.42 \\
\hline $\mathrm{LA}$ area, $\mathrm{cm}^{2}$ & $21 \pm 2^{\circ}$ & $23 \pm 5$ & $27 \pm 7$ & 0.002 \\
\hline GLS, \% & $24 \pm 7 \S$ & $24 \pm 5$ & $21 \pm 8$ & $<0.001$ \\
\hline GCS, \% & $24 \pm 3^{\circ}$ & $29 \pm 4$ & $27 \pm 8$ & 0.08 \\
\hline Myocardial LGE, n (\%) & $0(0)^{\circ}$ & $70(29)$ & $97(35)$ & 0.15 \\
\hline Ischemic type, n (\%) & $0(0)^{\circ}$ & $34(14)$ & $44(16)$ & 0.64 \\
\hline Non-ischemic, n (\%) & $0(0)^{\circ}$ & $36(15)$ & $53(19)$ & 0.37 \\
\hline Myocardial ischemia, n (\%) & $0(0)^{\circ}$ & $27(11)$ & $44(16)$ & 0.10 \\
\hline Native T1 (ms) & $1076 \pm 18^{\circ}$ & $1123 \pm 31$ & $1152 \pm 43$ & $<0.001$ \\
\hline Native T1 > 1167 ms (5SD cut-off) (\%) & / & $24(10)$ & $83(34)$ & $<0.001$ \\
\hline Native T2 (ms) & $35 \pm 1^{\circ}$ & $37 \pm 2$ & $41 \pm 4$ & $<0.001$ \\
\hline Native T2> 40 ms (2SD cut-off) (\%) & / & $43(17)$ & $117(46)$ & $<0.001$ \\
\hline \multicolumn{5}{|l|}{ Echo parameters } \\
\hline IVC diameter (mm) & $10.3 \pm 4^{\circ}$ & $9.8 \pm 4.6$ & $15.9 \pm 3.1$ & $<0.001$ \\
\hline IVC change (insp) (\%) & $57 \pm 6 \S$ & $58 \pm 14$ & $19 \pm 23$ & $<0.001$ \\
\hline
\end{tabular}

Bold indicated $p$-value $<0.05$

Mean $\pm \mathrm{SD}$, or median (IQR), $\mathrm{p}$-value $<0.05$ was considered significant

eGFR estimated glomerular filtration rate (in units, $\mathrm{ml} / \mathrm{min} / 1.73 \mathrm{~m}^{2}$ ), EDV end-diastolic volume, ESV end-systolic volume, EF ejection fraction, GLS global longitudinal strain, GCS global circumferential strain, LV left ventricular, LGE late gadolinium enhancement, IVC inferior vena cava, SD standard deviation

" $p$-value for comparison between patients' groups (eGFR $\geq 60$ vs eGFR $<59$ )

${ }^{\circ} \mathrm{p}<0.05$ vs non-CKD and CKD patients' groups

${ }^{\S} \mathrm{p}<0.05$ vs CKD patients' group
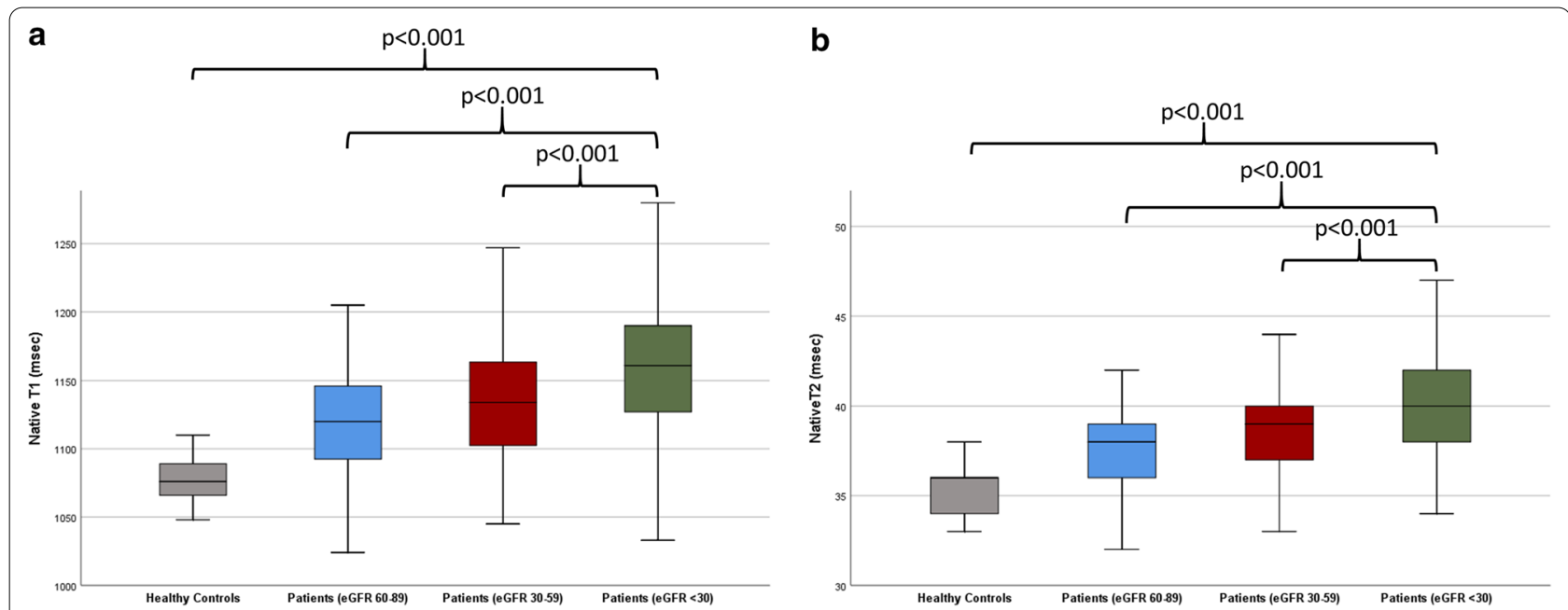

Fig. 3 Native T1 and T2 values across groups of healthy controls and patients with differential degree of CKD 

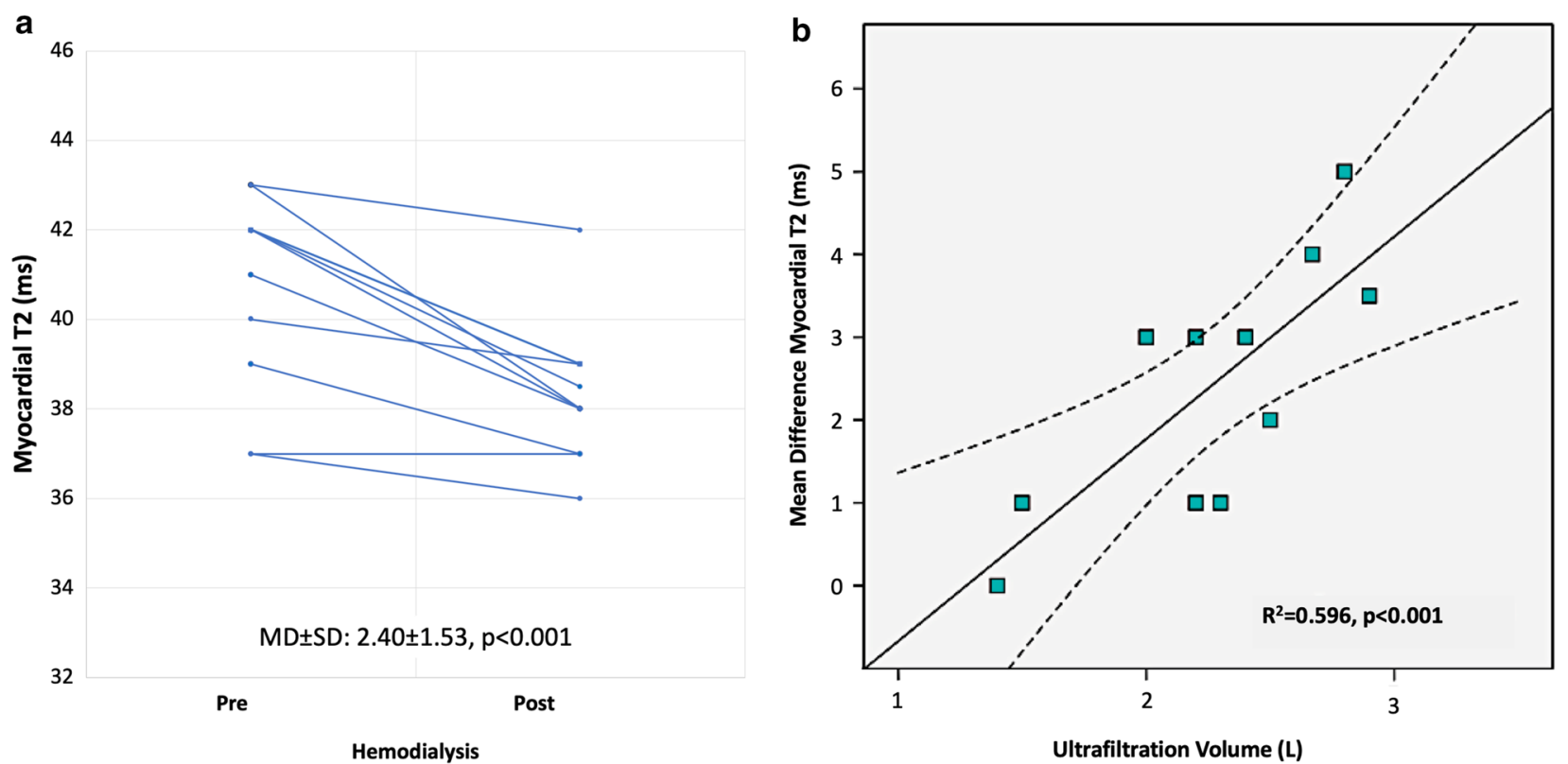

Fig. 4 Subgroup of participants undergoing a repeat CMR immediately after hemodialysis. a Graph showing significant native T2 reduction after hemodialysis. b Graph showing significant correlation between removed ultrafiltration volume and change in native T2. MD mean difference, SD standard deviation
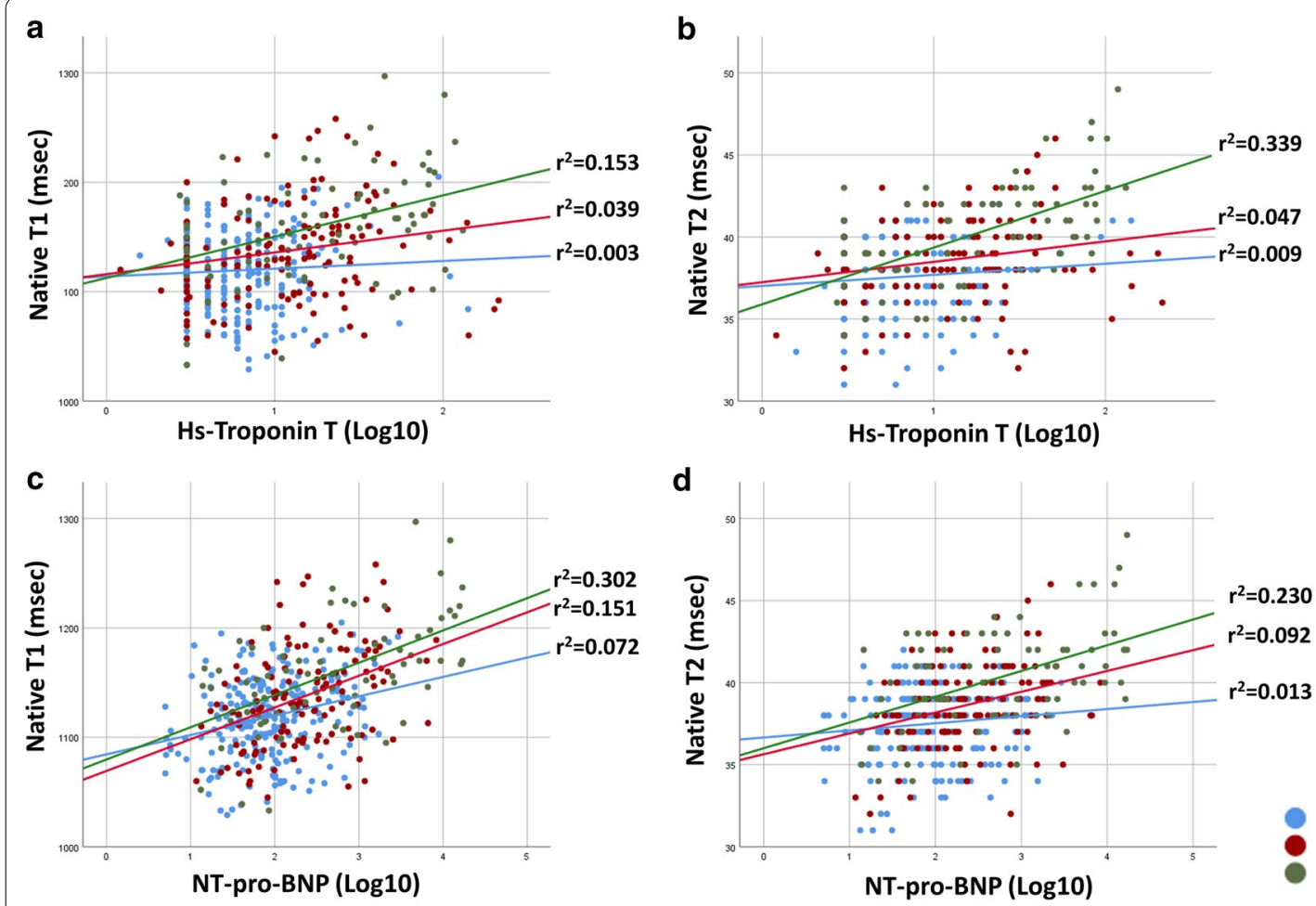

\section{Groups}

Patients (eGFR 60-89) Patients (eGFR 30-59)

Patients $(\mathrm{eGFR}<30)$

Fig. 5 Relationships between high sensitivity cardiac troponin Ths-cTnT $(\mathbf{a}, \mathbf{b})$ and N-terminal pro brain natriuretic peptide (NT-pro BNP) (c, d) with native T1 and T2 in patients with differential degrees of CKD. hs-CTnT high-sensitive cardiac troponin T, lg 10 log transformed 
Table 3 Univariable and multivariable linear regression analysis for factors associated with worsening CKD

\begin{tabular}{|c|c|c|c|c|}
\hline \multirow[t]{3}{*}{ Variable } & \multicolumn{4}{|l|}{ Worsening CKD } \\
\hline & \multicolumn{2}{|l|}{ Univariable } & \multicolumn{2}{|l|}{ Multivariable } \\
\hline & B (95\% Cl) & p-value & $\mathrm{B}(95 \% \mathrm{Cl})$ & p-value \\
\hline Hematocrit (\%) & $-0.193(-0.283$ to -0.103$)$ & $<0.001$ & NS & NS \\
\hline hs-CRP (Lg10) & $0.085(-0.006$ to 0.177$)$ & 0.068 & 0.098 (0.009 to 0.185$)$ & 0.031 \\
\hline LVEDV index $\left(\mathrm{ml} / \mathrm{m}^{2}\right)$ & 0.204 (0.114 to 0.293$)$ & $<0.001$ & NS & NS \\
\hline LV mass index $\left(\mathrm{g} / \mathrm{m}^{2}\right)$ & 0.208 (0.119 to 0.297$)$ & $<0.001$ & NS & NS \\
\hline LVEF (LVEF) & $-0.068(-0.159$ to 0.023$)$ & 0.143 & NS & NS \\
\hline GLS (\%) & $0.041(-0.050$ to 0.133$)$ & 0.376 & NS & NS \\
\hline LA area $\left(\mathrm{cm}^{2}\right)$ & 0.153 (0.054 to 0.251$)$ & 0.002 & NS & NS \\
\hline IVC variation (\%) & $-0.341(-0.427$ to -0.255$)$ & $<0.001$ & $-0.242(-0.357$ to -0.158$)$ & $<0.001$ \\
\hline LGE (presence) & $0.024(-0.067$ to 0.116$)$ & 0.600 & NS & NS \\
\hline Native T1 (ms) & 0.348 (0.263 to 0.434$)$ & $<0.001$ & 0.125 (0.022 to 0.235$)$ & 0.019 \\
\hline Native T2 (ms) & 0.385 (0.301 to 0.470$)$ & $<0.001$ & 0.272 (0.164 to 0.374$)$ & $<0.001$ \\
\hline
\end{tabular}

Bold indicated p-value $<0.05$

eGFR estimated glomerular filtration rate (in units, $\mathrm{ml} / \mathrm{min} / 1.73 \mathrm{~m}^{2}$ ), $\mathrm{Cl}$ confidence interval, $C R P C$-reactive protein, EV end-diastolic volume, EF ejection fraction, GLS global longitudinal strain, $L V$ left ventricular, LGE late gadolinium enhancement, IVC inferior vena cava

P-value $<0.05$ was considered significant

in patients with eGFR $<59 \mathrm{ml} / \mathrm{min} / 1.73 \mathrm{~m}^{2}$ only [eGFR $30-59 \mathrm{ml} / \mathrm{min} / 1.73 \mathrm{~m}^{2}: \mathrm{B}=0.308$ (95\% CI 0.129-0.407), $\mathrm{p}<0.001 ;$ eGFR $<29 \mathrm{ml} / \mathrm{min} / 1.73 \mathrm{~m}^{2}: \mathrm{B}=0.334(95 \% \mathrm{CI}$ 0.154-0.660), $\mathrm{p}=0.002$ ] and of hs-cTnT with native T2 in eGFR $<29 \mathrm{ml} / \mathrm{min} / 1.73 \mathrm{~m}^{2}$ only $[\mathrm{B}=0.417$ (95\% CI 0.219-0.650), $\mathrm{p}<0.001$ ] (Table 4).

\section{Reproducibility of measurements}

T1 and T2 mapping showed excellent intra- and interobserver agreement: native T1: intra-observer: $r=0.98$, $\mathrm{p}<0.01$, mean difference (MD) $\pm \mathrm{SD}-0.2 \pm 5.3 \mathrm{~ms}$; interobserver: $\mathrm{r}=0.96, \mathrm{p}<0.01, \mathrm{MD} \pm \mathrm{SD}-2.4 \pm 10.3 \mathrm{~ms}$. T2 mapping: intraobserver: $\mathrm{r}=0.98 ; \mathrm{MD} \pm \mathrm{SD}=-1.2 \pm 1.5$; interobserver $\mathrm{r}=0.96, \mathrm{p}<0.001 \mathrm{MD} \pm \mathrm{SD}=1.8 \pm 3.3$ ). GLS and GCS strain analysis, intra- and inter-observer agreements were moderate: GLS: intra-observer: $r=0.78$, $\mathrm{p}<0.001, \mathrm{MD} \pm \mathrm{SD}$ of $0.1 \pm 3.1$, interobserver: $\mathrm{r}=0.72$, $1.0 \pm 4.3$.

\section{Discussion}

In this prospective study, we demonstrate independent associations between cardiac biomarkers with imaging marker of myocardial edema and diffuse fibrosis, which are CKD-group specific. Native T1 and T2 were the only imaging markers to be independently associated with worsening CKD. Serological marker of increased LV wall stress, NT-pro BNP, and of myocardial injury, hs-cTnT, were independently associated with native $\mathrm{T} 1$ and $\mathrm{T} 2$ respectively, albeit only in patients with reduced renal function. Also, there was a significant reduction of native $\mathrm{T} 2$ when measured immediately post-hemodialysis with the change in $\mathrm{T} 2$ proportional to the removed ultrafiltration volume. Together, these results indicate a link between myocardial injury and LV wall stress with an increase of myocardial fluid, in addition to myocardial fibrosis, which is inherent to the presence of CKD.

Our observations expand the current knowledge about the pathophysiology of CVD and adverse myocardial remodeling in CKD. We employed two independent approaches of detecting myocardial abnormalities, by serology and imaging, which are both well established in terms of accuracy and prognostic significance $[3,8,10]$. Previous studies investigating the causes of raised troponin in CKD indicated that increased levels cannot be explained by the classical myocardial injury processes, such as such as infarction-like necrosis. Our findings lend support to this notion by showing that despite the higher CVD risk given by renal insufficiency, the rate of ischemic scar and myocardial ischemia or infarction was similar to that of the non-CKD group. Compared to a matched cohort of patients with eGFR $\geq 60 \mathrm{ml} / \mathrm{min} / 1.73 \mathrm{~m}^{2}$, but similar CVD risk factors by PSM of the two cohorts, we report elevated native $\mathrm{T} 1$ and $\mathrm{T} 2$, but not more prevalent LGE, reiterating that markedly raised troponin levels are unlikely fully explained by the consequences of atherosclerotic CAD [8]. Furthermore, we found that serological biomarkers hs-cTnT and NT-pro BNP and imaging markers of structural remodeling have closer correlation with native $\mathrm{T} 1$ and $\mathrm{T} 2$ as the renal function progressively declined. Together, these findings indicate that nonischemic processes play an important role in pathophysiology of myocardial injury in CKD [29]. 
Table 4 Univariable and multivariable linear regression analysis for factors associated with serological cardiac biomarkers according to different CKD stages

\begin{tabular}{|c|c|c|c|c|c|c|c|c|}
\hline \multirow[t]{4}{*}{ Variable } & \multicolumn{8}{|c|}{$\mathrm{eGFR} \geq 60 \mathrm{ml} / \mathrm{min} / 1.73 \mathrm{~m}^{2}$} \\
\hline & \multicolumn{4}{|l|}{ hs-cTnT (Lg10) } & \multicolumn{4}{|l|}{ NT-pro BNP (Lg10) } \\
\hline & \multicolumn{2}{|l|}{ Univariable } & \multicolumn{2}{|l|}{ Multivariable } & \multicolumn{2}{|l|}{ Univariable } & \multicolumn{2}{|l|}{ Multivariable } \\
\hline & B $(95 \% \mathrm{Cl})$ & p-value & B (95\% Cl) & p-value & B (95\% Cl) & $p$-value & B $(95 \% \mathrm{Cl})$ & $p$-value \\
\hline Hematocrit (\%) & $\begin{array}{l}-0.015(-0.106 \text { to } \\
0.083)\end{array}$ & 0.816 & NS & NS & $\begin{array}{l}-0.189(-0.263 \text { to } \\
-0.052)\end{array}$ & 0.004 & $\begin{array}{l}-0.233(-0.289 \text { to } \\
-0.099)\end{array}$ & $<0.001$ \\
\hline hs-CRP (Lg10) & $\begin{array}{l}0.062(-0.049 \text { to } \\
0.139)\end{array}$ & 0.344 & NS & NS & $\begin{array}{l}0.133(0.005 \text { to } \\
0.216)\end{array}$ & 0.041 & NS & NS \\
\hline LVEDV $\left(\mathrm{ml} / \mathrm{m}^{2}\right)$ & $\begin{array}{l}0.255(0.108 \text { to } \\
0.315)\end{array}$ & $<0.001$ & $\begin{array}{l}0.166(0.034 \text { to } \\
0.242)\end{array}$ & 0.1 & $\begin{array}{l}0.337(0.204 \text { to } \\
0.433)\end{array}$ & $<0.001$ & NS & NS \\
\hline $\begin{array}{l}\text { LV mass index ( } \mathrm{g} / \\
\mathrm{m}^{2} \text { ) }\end{array}$ & $\begin{array}{l}0.154(0.022 \text { to } \\
0.225)\end{array}$ & 0.018 & NS & NS & $\begin{array}{l}0.135(0.007 \text { to } \\
0.239)\end{array}$ & 0.038 & NS & NS \\
\hline LVEF (\%) & $\begin{array}{l}-0.253(-0.299 \text { to } \\
\quad-0.102)\end{array}$ & 0.001 & NS & NS & $\begin{array}{l}-0.427(-0.490 \text { to } \\
-0.280)\end{array}$ & $<0.001$ & $\begin{array}{l}-0.398(-0.465 \text { to } \\
-0.254)\end{array}$ & $<0.001$ \\
\hline GLS (\%) & $\begin{array}{l}0.221(0.069 \text { to } \\
0.251)\end{array}$ & 0.001 & NS & NS & 0.345 (0.15 to 0.385) & $<0.001$ & NS & NS \\
\hline $\mathrm{LA}\left(\mathrm{cm}^{2}\right)$ & 0.18 (0.038 to 0.238$)$ & 0.007 & NS & NS & $\begin{array}{l}0.298(0.149 \text { to } \\
0.369)\end{array}$ & $<0.001$ & $\begin{array}{l}0.208(0.079 \text { to } \\
0.282)\end{array}$ & 0.001 \\
\hline IVC variation (\%) & $\begin{array}{l}0.108(-0.02 \text { to } \\
0.231)\end{array}$ & 0.099 & NS & NS & $\begin{array}{l}-0.015(-0.160 \text { to } \\
0.126)\end{array}$ & 0.815 & NS & NS \\
\hline LGE (presence) & $\begin{array}{l}0.387(0.189 \text { to } \\
0.356)\end{array}$ & $<0.001$ & $\begin{array}{l}0.345(0.155 \text { to } \\
0.331)\end{array}$ & $<0.001$ & $\begin{array}{l}0.291(0.135 \text { to } \\
0.332)\end{array}$ & $<0.001$ & NS & NS \\
\hline Native T1 (ms) & $\begin{array}{l}0.059(-0.060 \text { to } \\
0.157)\end{array}$ & 0.368 & NS & NS & $\begin{array}{l}0.269(0.140 \text { to } \\
0.378)\end{array}$ & $<0.001$ & NS & NS \\
\hline Native T2 (ms) & $\begin{array}{l}0.096(-0.028 \text { to } \\
0.193)\end{array}$ & 0.141 & NS & NS & $\begin{array}{l}0.114(-0.013 \text { to } \\
0.237)\end{array}$ & 0.08 & NS & NS \\
\hline Variable & eGFR: 30-59 & & & & & & & \\
\hline Hematocrit (\%) & $\begin{array}{l}-0.097(-0.277 \text { to } \\
0.074)\end{array}$ & 0.256 & NS & NS & $\begin{array}{l}-0.165(-0.290 \text { to } \\
0.003)\end{array}$ & 0.055 & NS & NS \\
\hline hs-CRP (Lg10) & $\begin{array}{l}0.255(0.090 \text { to } \\
0.416)\end{array}$ & 0.003 & NS & NS & $\begin{array}{l}0.389(0.190 \text { to } \\
0.451)\end{array}$ & $<0.001$ & NS & NS \\
\hline LVEDV $\left(\mathrm{ml} / \mathrm{m}^{2}\right)$ & $\begin{array}{l}0.207(0.037 \text { to } \\
0.324)\end{array}$ & 0.014 & NS & NS & $\begin{array}{l}0.381(0.161 \text { to } \\
0.390)\end{array}$ & $<0.001$ & NS & NS \\
\hline $\begin{array}{l}\text { LV mass index (g/ } \\
\left.\mathrm{m}^{2}\right)\end{array}$ & $\begin{array}{l}0.291(0.133 \text { to } \\
0.463)\end{array}$ & $<0.001$ & $\begin{array}{l}0.218(0.018 \text { to } \\
0.428)\end{array}$ & $<0.001$ & $\begin{array}{l}0.308(0.123 \text { to } \\
0.400)\end{array}$ & $<0.001$ & NS & NS \\
\hline $\operatorname{LVEF}(\%)$ & $\begin{array}{l}-0.271(-0.381 \text { to } \\
\quad-0.096)\end{array}$ & 0.001 & NS & NS & $\begin{array}{l}-0.417(-0.419 \text { to } \\
-0.191)\end{array}$ & $<0.001$ & NS & NS \\
\hline GLS (\%) & $\begin{array}{l}0.281(0.119 \text { to } \\
0.444)\end{array}$ & 0.001 & NS & NS & $\begin{array}{l}0.467(0.260 \text { to } \\
0.514)\end{array}$ & $<0.001$ & $\begin{array}{l}0.319(0.117 \text { to } \\
0.405)\end{array}$ & $<0.001$ \\
\hline $\mathrm{LA}\left(\mathrm{cm}^{2}\right)$ & $\begin{array}{l}0.307(0.098 \text { to } \\
0.423)\end{array}$ & 0.002 & $\begin{array}{l}0.242(0.035 \text { to } \\
0.375)\end{array}$ & 0.002 & $\begin{array}{l}0.500(0.227 \text { to } \\
0.477)\end{array}$ & $<0.001$ & $\begin{array}{l}0.311(0.095 \text { to } \\
0.343)\end{array}$ & 0.001 \\
\hline IVC variation (\%) & $\begin{array}{l}0.02(-0.222 \text { to } \\
0.282)\end{array}$ & 0.813 & NS & NS & $\begin{array}{l}-0.065(-0.293 \text { to } \\
0.132)\end{array}$ & 0.454 & NS & NS \\
\hline LGE (presence) & $\begin{array}{l}0.256(0.087 \text { to } \\
0.394)\end{array}$ & 0.002 & NS & NS & $\begin{array}{l}0.368(0.162 \text { to } \\
0.412)\end{array}$ & $<0.001$ & NS & NS \\
\hline Native T1 (ms) & $\begin{array}{l}0.189(0.033 \text { to } \\
0.379)\end{array}$ & 0.025 & NS & NS & $\begin{array}{l}0.389(0.201 \text { to } \\
0.475)\end{array}$ & $<0.001$ & $\begin{array}{l}0.308(0.129 \text { to } \\
0.407)\end{array}$ & $<0.001$ \\
\hline Native T2 (ms) & $\begin{array}{l}0.217(0.057 \text { to } \\
0.410)\end{array}$ & 0.01 & NS & NS & $\begin{array}{l}0.304(0.126 \text { to } \\
0.418)\end{array}$ & $<0.001$ & NS & NS \\
\hline Variable & eGFR $<29$ & & & & & & & \\
\hline Hematocrit (\%) & $\begin{array}{l}-0.5(-0.73 \text { to } \\
-0.318)\end{array}$ & $<0.001$ & $\begin{array}{l}-0.307(-0.537 \text { to } \\
-0.107)\end{array}$ & 0.004 & $\begin{array}{l}-0.42(-0.736 \text { to } \\
-0.239) \\
\end{array}$ & $<0.001$ & $\begin{array}{l}-0.303(-0.575 \text { to } \\
-0.128)\end{array}$ & 0.003 \\
\hline
\end{tabular}


Table 4 (continued)

\begin{tabular}{|c|c|c|c|c|c|c|c|c|}
\hline Variable & eGFR $<29$ & & & & & & & \\
\hline hs-CRP (Lg10) & $\begin{array}{l}0.168(-0.061 \text { to } \\
0.432)\end{array}$ & 0.139 & NS & NS & $\begin{array}{l}0.167(-0.080 \text { to } \\
0.489)\end{array}$ & 0.157 & NS & NS \\
\hline $\operatorname{LVEDV~}\left(\mathrm{ml} / \mathrm{m}^{2}\right)$ & $\begin{array}{l}0.369(0.160 \text { to } \\
0.586)\end{array}$ & 0.001 & NS & NS & $\begin{array}{l}0.497(0.327 \text { to } \\
0.786)\end{array}$ & $<0.001$ & NS & NS \\
\hline $\begin{array}{l}\text { LV mass index ( } \mathrm{g} / \\
\left.\mathrm{m}^{2}\right)\end{array}$ & $\begin{array}{l}0.389(0.165 \text { to } \\
0.546)\end{array}$ & $<0.001$ & NS & NS & $\begin{array}{l}0.575(0.385 \text { to } \\
0.776)\end{array}$ & $<0.001$ & $\begin{array}{l}0.390(0.183 \text { to } \\
0.604)\end{array}$ & 0.001 \\
\hline $\operatorname{LVEF}(\%)$ & $\begin{array}{l}-0.135(-0.368 \text { to } \\
0.091)\end{array}$ & 0.234 & NS & NS & $\begin{array}{l}-0.305(-0.599 \text { to } \\
0.090)\end{array}$ & 0.009 & NS & NS \\
\hline GLS (\%) & $\begin{array}{l}0.251(0.037 \text { to } \\
0.548)\end{array}$ & 0.026 & NS & NS & $\begin{array}{l}0.401(0.237 \text { to } \\
0.796)\end{array}$ & $<0.001$ & NS & NS \\
\hline $\mathrm{LA}\left(\mathrm{cm}^{2}\right)$ & $\begin{array}{l}0.407(0.179 \text { to } \\
0.707)\end{array}$ & 0.001 & $\begin{array}{l}0.284(0.097 \text { to } \\
0.522)\end{array}$ & 0.005 & $\begin{array}{l}0.400(0.181 \text { to } \\
0.784)\end{array}$ & 0.002 & NS & NS \\
\hline IVC variation (\%) & $\begin{array}{l}-0.106(-0.275 \text { to } \\
0.100)\end{array}$ & 0.354 & NS & NS & $\begin{array}{l}-0.237(-0.430 \text { to } \\
-0.007)\end{array}$ & 0.043 & NS & NS \\
\hline LGE (presence) & $\begin{array}{l}0.174(-0.064 \text { to } \\
0.506)\end{array}$ & 0.127 & NS & NS & $\begin{array}{l}0.310(0.119 \text { to } \\
0.750)\end{array}$ & 0.008 & NS & NS \\
\hline Native T1 (ms) & $0.388(0.189-0.657)$ & $<0.001$ & NS & NS & $\begin{array}{l}0.549(0.423 \text { to } \\
0.904)\end{array}$ & $<0.001$ & $\begin{array}{l}0.334(0.154 \text { to } \\
0.660)\end{array}$ & 0.002 \\
\hline Native T2 (ms) & $0.583(0.415-0.799)$ & $<0.001$ & $\begin{array}{l}0.417(0.219 \text { to } \\
0.650)\end{array}$ & $<0.001$ & $\begin{array}{l}0.480(0.314 \text { to } \\
0.793)\end{array}$ & $<0.001$ & NS & NS \\
\hline
\end{tabular}

Bold indicated $p$-value $<0.05$

eGFR estimated glomerular filtration rate (in units, $\mathrm{ml} / \mathrm{min} / 1.73 \mathrm{~m}^{2}$ ), $C l$ confidence interval, $C R P$ C-reactive protein, $E V$ end-diastolic volume, $E S V$ end-systolic volume, $E F$ ejection fraction, GLS global longitudinal strain, LV left ventricular, LGE late gadolinium enhancement, IVC inferior vena cava

p-value $<0.05$ was considered significant

The independent association between native $\mathrm{T} 2$ and hs-cTnT in patients with severe CKD (eGFR $<29 \mathrm{ml} /$ $\mathrm{min} / 1.73 \mathrm{~m}^{2}$ ) is a central new finding, reiterating the role of increased myocardial fluid, in addition to myocardial fibrosis, as an integral part of structural LV remodeling in CKD [30]. In the literature, troponin release in CKD has been attributed to a number of mechanisms, including increased transmural pressure, small-vessel coronary obstruction, endothelial dysfunction, intracellular edema $[8,31,32]$, as well as direct cellular toxicity of the uremic milieu [33, 34]. Notably, we strived to control for myocardial inflammation by excluding subjects with suspected clinical presentation or positive histology for active inflammation, which could yield a similar imaging pattern [35]. Whether edema is a cause or a consequence of the myocardial damage, cannot be fully elucidated based on the current data. Recent studies revealed the dynamic changes in native $\mathrm{T} 2$ measurements induced by either ultrafiltration or diuretics in CKD and HF, respectively $[13,36]$. In a proof-of concept sub study, we reproduced this finding in a subgroup of participants that underwent a second scan immediately after HD. In addition to reduction of native T2 in this subgroup, we also found a trend of increasing association between native T2, hscTnT and NT-pro BNP with worsening of CKD stages, which may suggest that myocardial water content is increasing with worsening renal function, likely affected by the total body water content. This observation might point towards potential clinical implications. Despite discrete native $\mathrm{T} 1$ and $\mathrm{T} 2$ values overlap between non-CKD $\left(\right.$ eGFR $\left.\geq 60 \mathrm{ml} / \mathrm{min} / 1.73 \mathrm{~m}^{2}\right)$ and CKD $($ eGFR $<59 \mathrm{ml} /$ $\min / 1.73 \mathrm{~m}^{2}$ ) patients, which could reduce the added value of mapping assessment in this context, T2 exhibited significant correlation with cardiac injury in patients with severe renal insufficiency $\left(e G F R<29 \mathrm{ml} / \mathrm{min} / 1.73 \mathrm{~m}^{2}\right.$ ) only. Further studies are required to explore whether focused myocardial water-shifts might translate into a modifiable intervention conferring cardio-protection in some patients with advanced CKD, hypothetically those with higher T2 and hs-cTnT. We also observed an interrelatedness between $\mathrm{T} 1$ and $\mathrm{T} 2$, which becomes much stronger as renal function declines, indirectly supporting that both measures are much more influenced by excess myocardial fluid in CKD [10, 27]. Accordingly, native T1 is a nonspecific measure of interstitial expansion, detecting water as well as fibrosis [30], hence, an integrated reading along with $\mathrm{T} 2$ values and a patient's underlying renal function may aid the correct interpretation of this measure. Outcome data are needed to validate the prognostic relevance of our findings, as well as prospective trials of intervention algorithms based on the presented imaging readouts to ascertain whether their guidance can improve clinical care. 


\section{Limitations}

A few limitations of our study apply. We strived to control for inclusion bias in several ways. Respiratory variation of IVC was used as a proxy-measure of the total body fluid status, because it was obtainable in all subjects across the eGFR spectrum. Participants with reduced kidney function were recruited from tertiary centers as well as peripheral nephrology practices, thus reducing the potential referral bias. The clinical indications for CMR were uniform for both groups and approved by an independent cardiologist in line with cardiological practice guidelines. Native T1 moderately correlates with collagen volume fraction in model diseases of pressure overload (severe aortic stenosis, participants with eGFR $\geq 60 \mathrm{ml} / \mathrm{min} / 1.73 \mathrm{~m}^{2}$ ), however, histological correlations with myocardial fibrosis in CKD may differ and require verification in future studies. Myocardial edema cannot be validated by classical histology, as it is complicated by dehydration through tissue fixation with formaldehyde. However, a previous experimental study used a tissue desiccation method to provide validation of T2 mapping measurements against myocardial water content [37]. CMR examinations in the present study were performed as a part of clinical service, where the muchneeded time efficiency does not justify the use of rest perfusion imaging nor postcontrast $\mathrm{T} 1$ mapping.

\section{Conclusions}

In conclusion, we demonstrate independent associations between serological biomarkers with imaging markers of interstitial expansion, which are CKD-group specific. Our findings indicate the role of diffuse non-ischemic tissue processes, including excess of myocardial fluid in addition to diffuse fibrosis in CKD-related adverse remodeling.

\begin{abstract}
Abbreviations
BMI: Body mass index; BP: Blood pressure; CAD: Coronary artery disease: CKD: Chronic kidney disease; CMR: Cardiovascular magnetic resonance; CRP: C-reactive protein; CVD: Cardiovascular disease; eGFR: Estimated glomerular filtration rate; GBCA: Gadolinium-based contrast agent; GCS: Global circumferential strain; GLS: Global longitudinal strain; HF: Heart failure; hs-cTnT: Cardiac biomarkers troponin T; IVC: Inferior vena cava; IQR: Interquartile range; LA: Left atrium; LGE: Late gadolinium enhancement; LV: Left ventricle/left ventricular; LVEDV: Left ventricular end-diastolic volume; LVEF: Left ventricular ejection fraction; LVESV: Left ventricular end-systolic volume; LVH: Left ventricular hypertrophy; MDRD: Modification of Diet in Renal Disease; MOLLI: Modified Look-Locker inversion recovery; NSF: Nephrogenic systemic fibrosis; NT-pro BNP: NT-pro-brain nucleotide peptide; PSM: Propensity score matching; RVEF: Right ventricular ejection fraction; SD: Standard deviation; SE: Standard error.
\end{abstract}

\section{Supplementary Information}

The online version contains supplementary material available at https://doi. org/10.1186/s12968-021-00762-z.
Additional file 1: Figure S1: Heat map for correlations between mapping parameters with clinical and CMR findings at different CKD stages. A more intense color indicates closer association (blue for direct correlation, red for inverse correlation). NA (not applicable), eGFR-estimated glomerular filtration rate (in units, $\mathrm{ml} / \mathrm{min} / 1.73 \mathrm{~m}^{2}$ ), CRP-C-reactive protein, EDVend-diastolic volume, ESV-end-systolic volume, EF-ejection fraction, GLS—global longitudinal strain, LV—left ventricular, LGE-late gadolinium enhancement, IVC - inferior vena cava.

Additional file 2: Figure S2: Heat map for correlations between cardiac biomarkers and CMR imaging markers of adverse cardiac remodeling at different CKD stages. A more intense color indicates closer association (blue for direct correlation, red for inverse correlation). eGFR-estimated glomerular filtration rate (in units, $\mathrm{ml} / \mathrm{min} / 1.73 \mathrm{~m}^{2}$ ), EV-end-diastolic volume, ESV — end-systolic volume, EF-ejection fraction, GLS — global longitudinal strain, LV_-left ventricular, LGE-late gadolinium enhancement, IVC -inferior vena cava.

Additional file 3: Supplementary methods.

\section{Acknowledgements}

We thank our supporting staff for the dedicated hard work. This work is a tribute to a patient-centered multidisciplinary care between colleagues imagers, cardiologists, radiologists and nephrologists.

\section{Authors' contributions}

LA, EN and VP were involved in the concept and design of the study, LA and VP drafted the manuscript, LA, HZ, HaZ, MG, EN and VP performed CMR examinations, LA, HaZ, MG and VP performed echocardiograms, JE, TF, SB, HG and IH were involved in the care of CKD patients including planning and performing dialysis, all authors provided critical comments to the study. All authors read and approved the final manuscript.

\section{Funding}

Open Access funding enabled and organized by Projekt DEAL. German Ministry of Education and Research via the German Centre for Cardiovascular Research (DZHK) to EN, VP.

\section{Availability of data and materials}

None.

\section{Declarations}

\section{Ethics approval and consent to participate}

The study protocols were reviewed and approved by institutional ethics committee. Written informed consent was obtained from all participants.

\section{Consent for publication}

Informed consent was obtained from all the patients for the use of their data for scientific purposes.

\section{Competing interests}

There are no conflicts of interest to disclose.

\section{Author details}

${ }^{1}$ Institute of Experimental and Translational Cardiovascular Imaging, DZHK Centre for Cardiovascular Imaging, Goethe University Hospital Frankfurt, Frankfurt am Main, Germany. ${ }^{2}$ Cardiology Unit, Clinical and Molecular Medicine Department, Faculty of Medicine and Psychology, Sapienza University of Rome, Rome, Italy. ${ }^{3}$ Department of Nephrology, Goethe University Hospital Frankfurt, Frankfurt am Main, Germany. ${ }^{4}$ Department of Radiology, XiangYa Hospital, Central South University, Changsha, Hunan, China. ${ }^{5}$ Department of Cardiology, Universiti Teknologi MARA (UiTM), Sg. Buloh, Malaysia. ${ }^{6}$ Department of Cardiology, University Hospital Warsaw, Warsaw, Poland.

Received: 10 June 2020 Accepted: 28 April 2021

Published online: 07 June 2021 


\section{References}

1. Tonelli M, Wiebe N, Culleton B, House A, Rabbat C, Fok M, et al. Chronic kidney disease and mortality risk: a systematic review. J Am Soc Nephrol. 2006;17:2034-47. https://doi.org/10.1681/ASN.2005101085

2. Unger ED, Dubin RF, Deo R, Daruwalla V, Friedman JL, Medina C, et al. Association of chronic kidney disease with abnormal cardiac mechanics and adverse outcomes in patients with heart failure and preserved ejection fraction. Eur J Heart Fail. 2016;18:103-12. https://doi.org/10.1002/ ejhf.445.

3. Ponikowski P, Voors AA, Anker SD, Bueno H, Cleland JGF, Coats AJS, et al. 2016 ESC guidelines for the diagnosis and treatment of acute and chronic heart failure. Eur Heart J. 2016;37:2129-200. https://doi.org/10. 1093/eurheartj/ehw128.

4. Arcari L, Ciavarella GM, Altieri S, Limite LR, Russo D, Luciani M, et al. Longitudinal changes of left and right cardiac structure and function in patients with end-stage renal disease on replacement therapy. Eur J Intern Med. 2020. https://doi.org/10.1016/j.ejim.2020.04.051.

5. Apple FS, Sharkey SW, Hoeft P, Skeate R, Voss E, Dahlmeier BA, et al. Prognostic value of serum cardiac troponin I and T in chronic dialysis patients: a 1-year outcomes analysis. Am J Kidney Dis. 1997;29:399403. https://doi.org/10.1016/s0272-6386(97)90201-8.

6. Jacobs LH, Van De Kerkhof J, Mingels AM, Kleijnen VW, Van Der Sande FM, Wodzig WK, et al. Haemodialysis patients longitudinally assessed by highly sensitive cardiac troponin T and commercial cardiac troponin T and cardiac troponin I assays. Ann Clin Biochem. 2009;46:283-90. https://doi.org/10.1258/acb.2009.008197.

7. Parikh RH, Seliger SL, deFilippi CR. Use and interpretation of high sensitivity cardiac troponins in patients with chronic kidney disease with and without acute myocardial infarction. Clin Biochem. 2015:48:24753. https://doi.org/10.1016/j.clinbiochem.2015.01.004.

8. Thygesen K, Alpert JS, Jaffe AS, Chaitman BR, Bax JJ, Morrow DA, et al. Fourth universal definition of myocardial infarction (2018). Eur Heart J. 2019:40:237-69. https://doi.org/10.1093/eurheartj/ehy462.

9. Van Der Linden N, Cornelis T, Kimenai DM, Klinkenberg LJJ, Hilderink JM, Lück S, et al. Origin of cardiac troponin T elevations in chronic kidney disease. Circulation. 2017;136:1073-5. https://doi.org/10.1161/ CIRCULATIONAHA.117.029986.

10. Puntmann VO, Valbuena S, Hinojar R, Petersen SE, Greenwood JP, Kramer CM, et al. Society for cardiovascular magnetic resonance (SCMR) expert consensus for CMR imaging endpoints in clinical research: part i-analytical validation and clinical qualification. J Cardiovasc Magn Reson. 2018. https://doi.org/10.1186/s12968-018-0484-5.

11. Mangion K, McDowell K, Mark PB, Rutherford E. Characterizing cardiac involvement in chronic kidney disease using CMR-a systematic review. Curr Cardiovasc Imaging Rep. 2018;11:2. https://doi.org/10.1007/ s12410-018-9441-9.

12. Rutherford E, Talle MA, Mangion K, Bell E, Rauhalammi SM, Roditi G, et al. Defining myocardial tissue abnormalities in end-stage renal failure with cardiac magnetic resonance imaging using native $T 1$ mapping. Kidney Int. 2016;90:845-52. https://doi.org/10.1016/j.kint.2016.06 014.

13. Kotecha T, Martinez-Naharro A, Yoowannakul S, Lambe T, Rezk T, Knight DS, et al. Acute changes in cardiac structural and tissue characterisation parameters following haemodialysis measured using cardiovascular magnetic resonance. Sci Rep. 2019;9:1388. https://doi.org/10.1038/ s41598-018-37845-4

14. Puntmann VO, Carr-White G, Jabbour A, Yu C-Y, Gebker R, Kelle S, et al. T1-mapping and outcome in nonischemic cardiomyopathy all-cause mortality and heart failure. JACC Cardiovasc Imaging. 2016. https://doi. org/10.1016/j.jcmg.2015.12.001.

15. Puntmann VO, Carr-White G, Jabbour A, Yu C-Y, Gebker R, Kelle S, et al. Native T1 and ECV of noninfarcted myocardium and outcome in patients with coronary artery disease. J Am Coll Cardiol. 2018;71:76678. https://doi.org/10.1016/j.jacc.2017.12.020.

16. https://www.nice.org.uk/guidance/cg182. Last accessed 1st June 2020.

17. https://renal.org/information-resources/the-uk-eckd-guide/ckdstages/. Last accessed 1st Jun 2020.

18. Chen M, Arcari L, Engel J, Freiwald T, Platschek S, Zhou H, et al. Aortic stiffness is independently associated with interstitial myocardial fibrosis by native $T 1$ and accelerated in the presence of chronic kidney disease. IJC Heart Vasc. 2019;24:100389. https://doi.org/10.1016/J. IJCHA.2019.100389.

19. https://www.ema.europa.eu/en/medicines/human/referrals/gadol inium-containing-contrast-agents; https://www.fda.gov/drugs/postm arket-drug-safety-information-patients-and-providers/informationgadolinium-based-contrast-agents; https://www.acr.org/Clinical-Resou rces/Contrast-Manual. Last accessed on 1st June 2020.

20. https://car.ca/news/new-car-guidelines-use-gadolinium-based-contr ast-agents-kidney-disease/. Last accessed on 1st June 2020.

21. Verhaert D, Thavendiranathan P, Giri S, Mihai G, Rajagopalan S, Simonetti OP, et al. Direct T2 quantification of myocardial edema in acute ischemic injury. JACC Cardiovasc Imaging. 2011;4:269-78. https://doi. org/10.1016/j.jcmg.2010.09.023.

22. Dabir D, Child N, Kalra A, Rogers T, Gebker R, Jabbour A, et al. Reference values for healthy human myocardium using a T1 mapping methodology: results from the International T1 Multicenter cardiovascular magnetic resonance study. J Cardiovasc Magn Reson. 2014;16:69. https:// doi.org/10.1186/s12968-014-0069-x.

23. Jahrestagung der Deutsche Gesellschaft für Kardiologie- Herz- und Kreislaufforschung vom 4. bis 7. April 2018 in Mannheim 84th annual meeting of the German Cardiac Society-Cardiac and Circulation Research, April 4-7. 2018, Mannheim. Clin Res Cardiol 2018;107:1-1. https://doi.org/10.1007/s00392-018-1216-4.

24. Nagel E, Greenwood JP, McCann GP, Bettencourt N, Shah AM, Hussain ST, et al. Magnetic resonance perfusion or fractional flow reserve in coronary disease. N Engl J Med. 2019;380:2418-28. https://doi.org/10. 1056/NEJMoa1716734.

25. Galderisi M, Cosyns B, Edvardsen T, Cardim N, Delgado V, Di Salvo G, et al. Standardization of adult transthoracic echocardiography reporting in agreement with recent chamber quantification, diastolic function, and heart valve disease recommendations: an expert consensus document of the European Association of Cardiovascular Imaging. Eur Heart J Cardiovasc Imaging. 2017;18:1301-10. https://doi.org/10.1093/ ehjci/jex244.

26. Kramer CM, Barkhausen J, Bucciarelli-Ducci C, Flamm SD, Kim RJ, Nagel E. Standardized cardiovascular magnetic resonance imaging (CMR) protocols: 2020 update. J Cardiovasc Magn Reson. 2020. https://doi. org/10.1186/s12968-020-00607-1.

27. Child N, Suna G, Dabir D, Yap M-L, Rogers T, Kathirgamanathan M, et al. Comparison of MOLLI, shMOLLLI, and SASHA in discrimination between health and disease and relationship with histologically derived collagen volume fraction. Eur Heart J Cardiovasc Imaging. 2018;19:768-76. https://doi.org/10.1093/ehjci/jex309.

28. Pedrizzetti G, Claus P, Kilner PJ, Nagel E. Principles of cardiovascular magnetic resonance feature tracking and echocardiographic speckle tracking for informed clinical use. J Cardiovasc Magn Reson. 2016:18:51. https://doi.org/10.1186/s12968-016-0269-7.

29. Edwards NC, Moody WE, Yuan M, Hayer MK, Ferro CJ, Townend JN, et al. Diffuse interstitial fibrosis and myocardial dysfunction in early chronic kidney disease. Am J Cardiol. 2015;115:1311-7. https://doi.org/10. 1016/j.amjcard.2015.02.015.

30. Arcari L, Hinojar R, Engel J, Freiwald T, Platschek S, Zainal H, et al. Native $\mathrm{T} 1$ and $\mathrm{T} 2$ provide distinctive signatures in hypertrophic cardiac conditions - comparison of uremic, hypertensive and hypertrophic cardiomyopathy. Int J Cardiol. 2020. https://doi.org/10.1016/j.ijcard. 2020.03.002.

31. Kociol RD, Pang PS, Gheorghiade M, Fonarow GC, O'Connor CM, Felker GM. Troponin elevation in heart failure prevalence, mechanisms, and clinical implications. J Am Coll Cardiol. 2010;56:1071-8. https://doi.org/ 10.1016/j.jacc.2010.06.016

32. Januzzi JL, Filippatos G, Nieminen M, Gheorghiade M. Troponin elevation in patients with heart failure: on behalf of the third Universal Definition of Myocardial Infarction Global Task Force: Heart Failure Section. Eur Heart J. 2012;33:2265-71. https://doi.org/10.1093/eurhe artj/ehs191.

33. Franssen CFM, Navis G. Chronic kidney disease: RAAS blockade and diastolic heart failure in chronic kidney disease. Nat Rev Nephrol. 2013;9:190-2. https://doi.org/10.1038/nrneph.2013.39.

34. Dickhout JG, Carlisle RE, Austin RC. Interrelationship between cardiac hypertrophy, heart failure, and chronic kidney disease: endoplasmic 
reticulum stress as a mediator of pathogenesis. Circ Res. 2011;108:62942. https://doi.org/10.1161/CIRCRESAHA.110.226803.

35. Winau L, Hinojar Baydes R, Braner A, Drott U, Burkhardt H, Sangle S, et al. High-sensitive troponin is associated with subclinical imaging biosignature of inflammatory cardiovascular involvement in systemic lupus erythematosus. Ann Rheum Dis. 2018;77:1590-8. https://doi.org/ 10.1136/annrheumdis-2018-213661.

36. Verbrugge FH, Bertrand PB, Willems E, Gielen E, Mullens W, Giri S, et al. Global myocardial oedema in advanced decompensated heart failure. Eur Hear J Cardiovasc Imaging. 2017;18:787-94. https://doi.org/10. 1093/ehjci/jew131
37. Fernández-Jiménez R, Sánchez-González J, Aguero J, Del Trigo M, Galán-Arriola C, Fuster V, et al. Fast T2 gradient-spin-echo (T2-GraSE) mapping for myocardial edema quantification: first in vivo validation in a porcine model of ischemia/reperfusion. J Cardiovasc Magn Reson. 2015;17:92. https://doi.org/10.1186/s12968-015-0199-9.

\section{Publisher's Note}

Springer Nature remains neutral with regard to jurisdictional claims in published maps and institutional affiliations.
Ready to submit your research? Choose BMC and benefit from:

- fast, convenient online submission

- thorough peer review by experienced researchers in your field

- rapid publication on acceptance

- support for research data, including large and complex data types

- gold Open Access which fosters wider collaboration and increased citations

- maximum visibility for your research: over $100 \mathrm{M}$ website views per year

At BMC, research is always in progress.

Learn more biomedcentral.com/submissions 